\title{
Determinants of Stock Investment Decisions of Sub-urban Investors in Bangladesh
}

\author{
Shahanaz Akter ${ }^{1} \quad$ Mohammad Jahangir Alam²* \\ 1.Lecturer, Department of Finance and Banking, Jashore University of Science and Technology, Jashore, \\ Bangladesh.
}

2.Assistant Professor, Department of Accounting and Information Systems, Jashore University of Science and Technology, Jashore, Bangladesh.

\begin{abstract}
Stock market around the world regarded as one of the most dominant indicators of the economic development of a country. Although the economy of Bangladesh grows to ever apex in the year 2019, its capital markets show the worst condition ever and never represent the economic status of the country. Investors lost their confidence and their all rational investment decisions failed to yield capital gains over the years. Thus, the prime objective of this study is to explore the determining factors which instigate the sub-urban investors of Bangladesh in making their investment decisions in the stock market and to investigate the effects of socio-economic variables on the dominant factors. The study has been pursued through a questionnaire survey to collect data from the stock investors of suburban areas of Bangladesh. Principal Component Analysis (PCA) has been used as a factor extraction method. Descriptive statistics, independent-samples t-test, ANOVA, and Post-hoc tests were employed as statistical tools. PCA derived eight factors and fundamental analysis becomes the most dominant factor that affects the suburban investors in making decisions about a stock. Factor analysis also indicated that investment training, technical analysis, investment literacy training, investment consultancy, trade house proximity, insider trading mechanism, macro-economic factors determine investment decisions. Results of inferential statistics revealed that gender difference affects technical analysis; education level has a large effect on investment training and investment length has an effect on fundamental and technical analysis. However, factors do not differ based on investors' occupational background and investment training. Policymakers should give concentrated effort to stabilize the stock market as the investors are more concerned about fundamental and technical analysis as well as investment literacy.
\end{abstract}

Keywords: Capital Market, Sub-urban Investors, PCA, Fundamental analysis, Socio-economic variables, Bangladesh

DOI: $10.7176 / \mathrm{EJBM} / 12-21-07$

Publication date:July $31^{\text {st }} 2020$

\section{Introduction}

For any country's economic development, proper mobilization of funding from surplus units to the deficit unit is to be ensured and the financial market must be properly structured. In this mobilization mechanism and financial structure of an economy, the money market and capital market both are very crucial components. The money market provides a certain amount of interest gain to the investors as well as creates a burden or fixed claim on the debtors-industries and companies. On the other hand, the capital market provides investors the opportunity to dividend gain and capital gain according to their risk-taking and investment management capacity provided that economic condition is favorable. Moreover, the shareholders/investors get the opportunity to be owners of the invested companies up to their number of shares they purchase. Capital Market also provides the opportunity to the fund collectors- the companies the opportunity of not getting any fixed contract of repayment of the funds they have collected from the investors/ shareholders through equity share issuance. As such, both parties get benefitted. Meanwhile, by mobilizing the funds, the economy gets liquidity, and companies get motivated to grow and operate, which ultimately boosts up the GDP of a country. As such, capital market research is very crucial; not only for economic development but also for deriving the possible ways to upgrade an emerging market like the Bangladeshi Capital market to an efficient market.

The capital market of Bangladesh is one of the smallest markets in the Asian region and the third-largest in South Asia. Although the stock exchanges were formed and started operations within 1954, there were no significant activities in the stock market until 1990 with inadequate regulatory structures, weak and obsolete market regulations, and the absence of proper enforcement of laws. However, in 1996, the first bubble formed, and burst out resulted in a share market crash. After this crash, the regulators felt the actual need for the formation and enforcement of strict and enforceable rules and legislations. Trade became automated with the introduction of CDBL in the stock market. The entry of almost all commercial banks, multinational companies, and profitable government entities intensified the growth process of the stock market. The investors got inspired and the market started to boost up, transformed into the bubble, and burst out again at the end of 2010 and continued its disaster on investors till 2011. These two bubbles were sharing some common traits. The common people joined the rally 
of the bubble investment in the stock market and the scammers got the chance to sell off their portion and left the general stockholders in the market. Then the market fell sharply and the general people got stuck with their investment in the capital market. Most of the people waited for the market to be corrected and expected the market will go upward again within a few days. But they lost more than they expected. Many investors borrowed money for this investment from relatives, friends, family, and even from banks and credit cards for the greed of profit from this bubble and they got nothing from the stock market except huge loss. Investors' greed, speculation, envy, and overconfidence formed the bubble, and capital-protecting and loss-minimizing policies like lack of selfconfidence, frustration, panic, and distrust caused the burst out (Rahman et al., 2017). Investor decisions to invest in stock were mostly based on psychological and behavioral finance rather than financial analysis. Rumor and insider information also played a vital role in investment decisions during this period. After the shock of 2010-11, the capital market of Bangladesh could not gather that vibe again. The general investors got panicked about stock market investment after these shocks, and now, many investors are not interested in investing in the stock market as well as many investors have become high risk-averse. Apart from these factors, how the sub-urban stock investors make decisions in investment in the stock market is still a matter of research. Besides these, demographic and socio-economic variables such as education level of investors, gender, age, investors experience, length of capital market investment, sources of capital, perception of society, religious factors affect the investment decision.

Therefore the objective of this study is to extract the factors that instigate the sub-urban investors of Bangladesh to invest in the stock market and to check whether these factors differ based on socio-economic variables.

Previous studies conducted on the factor affecting investment behavior of Bangladeshi investors in the stock market have focused on the investors trading at different brokerage houses of big cities like Dhaka, Chittagong, and Khulna (Rashid \& Nishat, (2009); Farzana et al., 2012; Faruqui \& Rahman, 2013; Akhter \& Ahmed, 2013; Khan et al., 2015; Hossain \& Nasrin, 2012; Jannatunnesa, 2017). However, studies on the investment behavior in stock of sub-urban investors of Jashore, Faridpur, and Kushtia are scant. Moreover, the socio-economic attributes of suburban areas are different from big cities. The present study also unique in the sense that it endeavored to investigate the effect of socio-economic attributes on the factors affecting the investment behavior of sub-urban investors.

\section{Literature Review and Hypotheses}

\subsection{Factor components of investment decision}

According to the traditional theory of finance, the investors' trading strategies depend on their risk tolerance ability and expectation of return. But other studies support that, investors behave abnormally which are different compared to the normal investment behavior of the investors. Some factors are responsible for these abnormal behaviors. Prior studies on the determinants of investment behavior relating to stock investments in different corners of the world revealed some interesting findings. According to Merikas et al. (2004), the classic wealth maximization goal influences the trading behavior of the investors. The most important factors identified are accounting information published by the company, financial requirements, personal perception, advocacy of the others, and individual data. Existing literature provides evidence that accounting information (Merikas et al., 2004; Afroze et al., 2015), Dividend growth (Balke \& Wohar, 2006), Inflation and interest rate (Al-Qenae, 2002), Financial Literacy (Al-Tamimi \& Kalli, 2009), Macroeconomic factors (Tsoukalas, 2003), Earning per Share (Bhatt \& Sumangula, 2012), political situation (Bennet \& Selvam, 2011), long term growth, high return, postretirement income (Kumar \& Sriram, 2018) are the dominant factors that determine investment decisions of investors. The study conducted by Rashid et al. (2009) pointed out the crucial factors on which Bangladeshi investors depend on is the inflation rate, efficiency of the company (macroeconomic factors), quick and easy transactions, transaction cost, access to the industry and company data, of information quality and previous investment knowledge. Husain et al. (2012) provided evidence that the company-specific features, NAV, financial information, reputation, advertisements, ownership constituents, and personal financial requirements are significant for investment decision making. Research conducted on the investors of UAE capital markets by AlTamimi (2006) reveals that preceding stock performance, expected earnings, marketability of stock, desire to get rich quickly, structured financial market, and government holdings are the most dominant individual factors that determine investment decisions. Joshi, Khusboo, and Desai (2011) indicated that the company's financial performance, performance trends in the long term, attitude towards the stock market, bonus share, cash dividend, company repute, stock market movement are the key factors in the investment decision. Sehgal and Tripathi (2007) found that firm size, book value to market equity, $\mathrm{P} / \mathrm{E}$ ratio, and leverage affects stock prices. Examining Malaysian investors Chong and Lai (2011) pointed out the past performance of firms' stock, recent price movement, and a firm's image in the industry as determining factors of investment decision. Corporate earnings, dividend, past performance, and financial statement analysis are the dominant factors among 30 variables as identified by Ahmed (2017). In extensive research, pursued by Williams (2007) on 5,170 investors revealed that investors evaluate the company's social and environmental behavior in investment decision making. Another study pursued by Sevil et 
al. (2007) provided evidence that, investors are not entirely rational decision-makers, as the traditional theory of finance suggests various human mindsets, expectations, and sentiments influence index prices. Haque and Faruquee (2013) stated that the investors' high expectations and irrational mindsets about investing can raise the irrational market index. Studies on behavioral finance are generated from the mismatch among the investment behavior of the investors and the theories of market efficiency and asset pricing model.

In many studies, it has been revealed that individual investors are affected by different behavioral biases (Kim $\&$ Nofsinger, 2008). A study pursued on the Nepalese Capital market by Kadariya et al. (2012), provided evidence that the information, both tangible and intangible is crucial in investment decisions. Moreover, Capital structure and average pricing method of the firm influence decisions. In addition to that, this research also found a positive relationship between investment decision making and different factors like political environment and media coverage, belief on luck, trend analysis, and financial education. A study on the investors of the Chittagong Stock exchange by Sarbabidya \& Saha (2018) revealed that risk factors, stockholders' whimsical attitude, EPS, political instability, and macroeconomic factors affect investment decisions. As such, it is important to see, how the suburban area's investors make investment decisions and what factors influence this decision-making process. Khan et al. (2015) identified the greater effects of market factors, economic factors, and hedging factors on investing decisions.

\subsection{Influence of socio-economic factors}

Some researchers tried to investigate whether demographic and socio-economic variables such as education level, marital status, age, gender, etc. have effects on different determents of investment decisions or not (Bajtelsmit and Bernasek, 2001; Collard, 2009). Investment decisions may vary based on the gender level. Women can tolerate a lower risk than that of men (Grable and Lytton, 1998). Bajtelsmit \& Bernasek (2001) and Collard (2009) found that women tend to have risk-averse compared to men. Factors and risk-taking attitude differs based on age. Younger people get more time to recover for loss than elder ones (Grable and Lytton, 1998). Aren \& Aydemir (2015) indicate that marital status, age, and society criterion creates no difference in choice of investment alternatives. On the other hand, Obamuyi (2001) found that age, education, marital status, and gender significantly influence the investment decision of Nigerian investors. Geetha \& Ramesh (2012) showed that age, gender, education, income, occupation, family size, and savings have significant influence over investment decisions. Metawa et al. (2019) identified significant positive effects of age, gender, and the level of education on investment decisions. Their findings also reveal that investors overlook emotional factors with the experience they gather from investment in the stock market. From the extensive review of existing literature and perception obtained from the socio-economic attributes of the sample investors, the researchers developed five hypotheses.

$\boldsymbol{H}_{1}$ : Gender has no significant effect on the dominant factors of investment decisions.

$\boldsymbol{H}_{2}$ : Investors' education level has no significant effect on the dominant factors of investment decisions.

$\boldsymbol{H}_{3}$ : Investors' occupational background has no significant effect on the dominant factors of investment decisions

$\boldsymbol{H}_{4}$ : Professional investment training has no significant effect on the dominant factors of investment decisions

$\boldsymbol{H}_{5}$ : Investment lengths (in years) has no significant effect on the dominant factors of investment decisions

\section{Data and Methodology}

\subsection{Sample selection and data collection}

This study aimed at finding out the factors which affect the stock investment decision making of sub-urban investors. In this pursuit, respondents are selected from the brokerage houses of three sub-urban districts of Khulna division namely Jashore, Kushtia, and Faridpur. A sample of 100 sub-urban investors was chosen using a nonprobability (purposive) sampling method. Data has been collected in January and February of 2020 during office hours of brokerage houses.

Primary data has been collected through a questionnaire comprising of structured and some open-ended questions. The questionnaire was divided into three sections based on the objectives of the study. The first section of the questionnaire comprised of demographic and socio-economic variables. The second section comprised questions of relative perception of the respondents measured on a 5-point Likert-scale ranging from 1(strongly disagree) to 5 (strongly agree). Twenty four questions have been selected for this section based on extensive literature review; consultations with professional investment companies, academicians, and general investors. The third section of the questionnaire comprised the open-ended questionnaire to have opinions on the additional factors which may affect their investment decisions.

In addition to that, secondary data were collected from various scholarly journals, articles, published materials, survey reports, internship reports, newspapers, online web contents, books, and websites of different regulatory authorities of financial markets in Bangladesh.

\subsection{Variable Identification and analysis technique}

All the descriptive and inferential statistics results were computed using SPSS version 25.0 for windows. Data 
collected through questionnaire were coded properly and checked for missing or outliers in data and found appropriate for analysis. Twenty four Likert-type data were coded as variable 1(V1) to variable 24(V24) respectively. These variables were used as items for factors analysis to extract the important factors components (latent variables) in order of importance in investors' decision making of sub-urban investors. All other required tests through SPSS were conducted to verify the suitability of data for Principal Component Analysis (PCA). Demographic and socio-economic data have been used as independent variables to test our set hypotheses. Independent sample's t-test for gender and ANOVA has been used for the other four socio-economic variables to test the effect of these variables on the dominant factors (Derived from PCA) of investment decisions.

\section{Empirical Results and Discussions}

\subsection{Descriptive statistics of the socio-economic variables:}

Among the tested samples, $81 \%$ were male, and $19 \%$ were female. $47 \%$ of the investors belong to the age group of $31-40$ years, only $10 \%$ of the investors were teenagers, $20 \%$ were aged $21-30$ years; only $23 \%$ of them have age more than 40 years. $49 \%$ of investors have an undergrad level of education, and $39 \%$ of investors have postgraduation levels of education. 5\% of investors have Higher Secondary Certificate (HSC), 3\% have Secondary School Certificate (SSC), and 4\% are below SSC. The frequency of occupational background indicates $31 \%$ are from business, $21 \%$ from government service, $20 \%$ from the agricultural sector, $16 \%$ from the private job, and the rest of the $12 \%$ are from other jobs. $75 \%$ of the investors of the target test had non-certificate training/ no formal training on investment analysis of the stock market, but another $25 \%$ have. Among the target investors $51 \%$ were involved in this business for $0-5$ years; $25 \%$ have experience of 6-10 years; $12 \%$ have experience of $11-15$ years and only 5\% have experience over 20 years. As such, $45 \%$ observed stock market crash of the year 2010-11, and only 5\% observed both crashes of the year 1996 and the year 2010-11. However, 44\%of the investors reported that, they become risk-averse as an effect of these market disasters and $44 \%$ reported that, they are not affected by these crashes, but the rest $12 \%$ were neutral after the crashes. The rate of loss effect is higher than the crash observers as some of them were not directly investing in the market, but they became risk-averse as they saw the market crashed. The average monthly income of the tested investors was Tk. 50000.00. Though many investors reported that they only incur an average monthly loss, but average monthly income from the stock market they get is Tk. 10000.00 .

\subsection{Result and discussions on Factor Analysis (EFA-PCA):}

The Likert-scale data related to factors of stock investment by sub-urban investors were examined using PCA with 'Varimax with Keiser Normalization' method through SPSS. The initial inspection of R-matrix indicated a sufficient number of coefficients above 0.30. The KMO Measure of Sampling Adequacy was 0.681, exceeding the required value of 0.60 (Kaiser, 1970) and Bartlett's Test of Sphericity (Bartlett, 1954) shows statistical significance $(\mathrm{p}<.001)$, assured that our data are suitable for Factor Analysis.

Table 1: KMO and Bartlett's Test

\begin{tabular}{lrr}
\hline Kaiser-Meyer-Olkin Measure of Sampling Adequacy. & .681 \\
\hline Bartlett's Test of Sphericity & Approx. Chi-Square & 693.954 \\
& df & 231 \\
& Sig. & .000 \\
\hline
\end{tabular}

The result of the initial analysis with 24 items showed some cross-loading for two items and after deduction of these two items the PCA with Varimax rotation has been run again. The results revealed eight latent factors with no Communalities less than .30 and Eigenvalues greater than 1, explaining $15.31 \%, 10.79 \%, 8.30 \%, 8.29 \%$, $7.20 \%, 6.87 \%, 6.71 \%$, and 5.76\% respectively considering Rotation Sums of Squared Loadings. The cumulative variance explained is $69.27 \%$ which is sufficient to explain the determining factors. 
Table 2: Extracted factors and Total Variance Explained

\begin{tabular}{|c|c|c|c|c|c|c|c|c|c|}
\hline \multirow{2}{*}{} & \multicolumn{3}{|c|}{ Initial Eigenvalues } & \multicolumn{3}{c|}{$\begin{array}{c}\text { Extraction Sums of Squared } \\
\text { Loadings }\end{array}$} & \multicolumn{3}{c|}{$\begin{array}{c}\text { Rotation Sums of Squared } \\
\text { Loadings }\end{array}$} \\
\cline { 2 - 11 } Component & Total & $\begin{array}{c}\text { \% of } \\
\text { Variance }\end{array}$ & Cumulative \% & Total & $\begin{array}{c}\text { \% of } \\
\text { Variance }\end{array}$ & Cumulative \% & Total & $\begin{array}{c}\text { \% of } \\
\text { Variance }\end{array}$ & Cumulative \% \\
\hline 1 & 4.837 & 21.989 & 21.989 & 4.837 & 21.989 & 21.989 & 3.369 & 15.316 & 15.316 \\
\hline 2 & 2.187 & 9.942 & 31.931 & 2.187 & 9.942 & 31.931 & 2.374 & 10.791 & 26.107 \\
\hline 3 & 1.969 & 8.950 & 40.881 & 1.969 & 8.950 & 40.881 & 1.828 & 8.308 & 34.415 \\
\hline 4 & 1.604 & 7.292 & 48.173 & 1.604 & 7.292 & 48.173 & 1.825 & 8.297 & 42.712 \\
\hline 5 & 1.268 & 5.762 & 53.934 & 1.268 & 5.762 & 53.934 & 1.584 & 7.200 & 49.912 \\
\hline 6 & 1.200 & 5.454 & 59.388 & 1.200 & 5.454 & 59.388 & 1.513 & 6.879 & 56.791 \\
\hline 7 & 1.113 & 5.057 & 64.445 & 1.113 & 5.057 & 64.445 & 1.477 & 6.714 & 63.505 \\
\hline 8 & 1.061 & 4.821 & 69.267 & 1.061 & 4.821 & 69.267 & 1.267 & 5.761 & 69.267 \\
\hline
\end{tabular}

The researchers followed the best-practiced criteria for factor retention and table 3 shows 22 factors were retained with eight latent factor components. Eight items (V1, V2, V3, V13, V14, V19, V21, and V23) were loaded on factors 1; three items (V8, V9 and V16) on factor 2; three items (V6, V17, and 18) on factor 3: two items (V4 and V5) on factor 4; two items (V7 and V22) on factor 5; two items (V10 and V11) on factor 6; V20 on factor 7 and V24 on factor 8.

Table 3: Factors Loadings of the variables in different components

\begin{tabular}{|c|c|c|c|c|c|c|c|c|}
\hline \multicolumn{9}{|c|}{ Rotated Component Matrix } \\
\hline \multirow[b]{2}{*}{ Variables/Items of components } & \multicolumn{8}{|c|}{ Factor Components } \\
\hline & 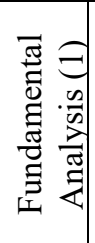 & 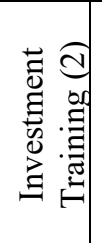 & 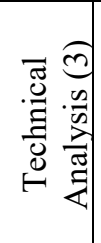 & 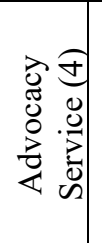 & 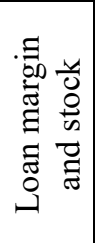 & 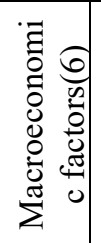 & 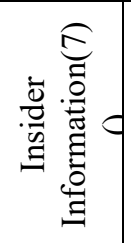 & 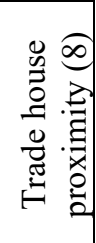 \\
\hline V3 Accounting information & 0.78 & & & & & & & \\
\hline V14 Dividend Declaration & 0.72 & & & & & & & \\
\hline V1 Key Financial Ratio analysis & 0.68 & & & & & & & \\
\hline V19 Capital structure and fund management & 0.66 & & & & & & & \\
\hline V21 Business expansion/merger/ acquisition & 0.51 & & & & & & & \\
\hline V13 Corporate profitability & 0.50 & & & & & & & \\
\hline V23 Owner's/ Management's background & 0.48 & & & & & & & \\
\hline V8 Investment literacy & & 0.82 & & & & & & \\
\hline V9 Professional Investment Training & & 0.82 & & & & & & \\
\hline V16 Internet knowledge & & 0.64 & & & & & & \\
\hline V18 Trends in stock price & & & 0.79 & & & & & \\
\hline V17 Past performance and future projection & & & 0.64 & & & & & \\
\hline V6 Risk tolerance level & & & 0.61 & & & & & \\
\hline $\begin{array}{l}\text { V5 Trader's Advocacy/professional investment } \\
\text { consultancy }\end{array}$ & & & & 0.76 & & & & \\
\hline V4 Peer Investor's Advocacy & & & & 0.75 & & & & \\
\hline V22 High margin loan & & & & & 0.81 & & & \\
\hline V7 Share's stock category & & & & & - & & & \\
\hline V10 Political unrest & & & & & & 0.76 & & \\
\hline V11 Interest rate and inflation & & & & & & 0.60 & & \\
\hline V20 Insider trading mechanism & & & & & & & 0.76 & \\
\hline V2 Company's brand value and image & 0.50 & & & & & & -0.53 & \\
\hline V24 The proximity of the Trade house & & & & & & & & 0.81 \\
\hline
\end{tabular}


in this factor component includes Accounting information, Dividend Declaration, Key Financial Ratio analysis, Capital structure and fund management, Business expansion/merger/ acquisition, Corporate profitability, Owner's/ Management's background, and Company's brand value and image. The mean of this factor is 3.89 with SD $=.64002$ and inter-item correlation is also satisfactory. The Reliability Statistics through Cronbach's Alpha is .795 implies a strong internal consistency among the items loaded in the factor.

Table 4: Cronbach's Alpha Reliability test

\begin{tabular}{|c|c|c|}
\hline \multicolumn{3}{|c|}{ Reliability Statistics } \\
\hline Cronbach's Alpha & Cronbach's Alpha Based on Standardized Items & N of Items \\
\hline .795 & .805 & 8 \\
\hline
\end{tabular}

Investment Training (factor 2) appeared as the second important factor loaded in table 3. This factor loaded the factors relating to the investment learning process of the investors in making decisions about a certain stock. Items included in this factor are Investment literacy, Professional Investment Training, and Internet knowledge about stock investment. The mean of this factor is 3.91 and the reliability statistics (Cronbach's Alpha $=0.746$ ) indicates a high internal consistency among the items included in the factor.

Factor three related to the technical analysis of the stock to be invested which covers $8.29 \%$ of the total variance explained by all the factors. Risk tolerance, trend analysis, and future outlook of the company are the main items of this factor. Item mean of this factor is 3.61and Cronbach's Alpha is 0.60 indicates satisfactory consistency among variables of this component.

It is evident from the analysis that investors take peer group and professional advice in making their decision before investing in a stock. Data analysis also revealed that investors are much concerned about the stock category, macroeconomic factors such as political unrest and interest rate fluctuations. Some investors depend on insider information (factor mean $=3.51$ ). However, trade house proximity has become an important factor $($ mean $=4.19)$ which instigates the sub-urban investor to invest in the stock market.

\subsection{Result of hypothesis testing of the five most influential factors and socio-economic factors}

\subsubsection{Gender and factors affecting investment decision}

An independent samples t-test was run to compare the mean scores of influential factors with 81 males and 19 female investors among sub-urban investors. Levene's Test of Homogeneity of Variances suggested Equality of Variances among groups.

Table 5: t-test for influence of gender on factor components

\begin{tabular}{|l|c|c|c|c|}
\hline \multicolumn{1}{|c|}{ Factor components } & \multicolumn{2}{c|}{ Mean } & \multirow{2}{*}{ t-value } & \\
\hline Fundamental Analysis & Male & Female & & .262 \\
\hline Investment Training & 0.05 & -0.23 & 1.129 & .125 \\
\hline Technical Analysis & -0.06 & 0.24 & -1.566 & $.026^{*}$ \\
\hline Advocacy Service & -0.11 & 0.46 & -2.261 & .169 \\
\hline Trade House Proximity & -0.07 & 0.28 & -1.386 & .518 \\
\hline
\end{tabular}

*The mean difference is significant at the 0.05 level

The result indicates a significant difference between male and female on factors relating to technical analysis $\{\mathrm{t}(98)=-2.261, \mathrm{p}=.026,95 \%$ confidence interval $\}$. Hence, our null hypothesis is rejected and indicates that gender difference is an issue to consider in technical analysis of the stock investment. However, the results show no significant difference in opinion on other influential factors. Hence, we failed to reject the null hypothesis for other influential factor components.

\subsubsection{Investors' education and factors affecting investment decision}

A one way ANOVA was run to investigate the differences in opinion among different educational groups on factors affecting investment decisions.

Table 6: ANOVA for Investors' education and investment decision factors (Between Groups)

\begin{tabular}{|l|c|c|c|c|}
\hline Factor components & Sum of Squares & Mean Square & F & Sig. \\
\hline Fundamental Analysis & 6.096 & 1.524 & 1.558 & .192 \\
\hline Investment Training & 17.398 & 4.349 & 5.064 &. $\mathbf{0 0 1 *}$ \\
\hline Technical Analysis & 3.362 & 0.841 & 0.835 & .506 \\
\hline Advocacy Service & 5.384 & 1.346 & 1.366 & .252 \\
\hline Trade House Proximity & 3.485 & 0.871 & .0867 & .487 \\
\hline
\end{tabular}

*The mean difference is significant at the 0.05 level

The result of ANOVA to assess the perception that education levels of investors on determinants of investment decision reveals that there exists a significant difference in opinion of all the respondents of various education levels regarding factors included in investment training ( $F=5.064, p=.001)$ components. The result indicates that investment training is a vital ingredient that affects an investment decision. The effect size under 
Cohen's d Criteria, calculated using eta squired was .18 implies education level has a large effect of investment training-related factors. No significant difference has been observed for other factor components under consideration.

To derive multiple comparisons among different levels of education assigned for this study Games-Howell Post Hoc Tests were used and as Levene's Test of Homogeneity of Variances found significant for one factor, Welch's Robust Tests of Equality of Means has been employed in this study.

Table 7: Games-Howell Post Hoc Tests of multiple comparison for investors education

\begin{tabular}{|c|c|c|c|c|}
\hline \multicolumn{5}{|c|}{ Dependent Variable: Investment Training } \\
\hline $\begin{array}{c}\text { (I) Investor's Education } \\
\text { level }\end{array}$ & $\begin{array}{c}\text { (J) Investor's Education } \\
\text { Level }\end{array}$ & $\begin{array}{l}\text { Mean Difference (I- } \\
\mathbf{J})\end{array}$ & $\begin{array}{l}\text { Std. } \\
\text { Error }\end{array}$ & Sig. \\
\hline \multirow[t]{4}{*}{ Below SSC } & $\mathrm{SSC}$ & 0.485 & 1.105 & .989 \\
\hline & HSC & 0.195 & 0.760 & .999 \\
\hline & Undergraduate & -0.243 & 0.618 & .993 \\
\hline & Post Graduate & -0.951 & 0.619 & .602 \\
\hline \multirow[t]{4}{*}{$\mathrm{SSC}$} & Below SSC & -0.485 & 1.105 & .989 \\
\hline & HSC & -0.291 & 1.034 & .998 \\
\hline & Undergraduate & -0.728 & 0.934 & .918 \\
\hline & Post Graduate & -1.437 & 0.935 & .627 \\
\hline \multirow[t]{4}{*}{ HSC } & Below SSC & -0.195 & 0.760 & .999 \\
\hline & $\mathrm{SSC}$ & 0.291 & 1.034 & .998 \\
\hline & Undergraduate & -0.437 & 0.479 & .881 \\
\hline & Post Graduate & -1.146 & 0.480 & .263 \\
\hline \multirow[t]{4}{*}{ Undergraduate } & Below SSC & 0.243 & 0.618 & .993 \\
\hline & $\mathrm{SSC}$ & 0.728 & 0.934 & .918 \\
\hline & HSC & 0.437 & 0.479 & .881 \\
\hline & Post Graduate & $-.70869367 *$ & 0.189 & .003 \\
\hline \multirow[t]{4}{*}{ Post Graduate } & Below SSC & 0.951 & 0.619 & .602 \\
\hline & SSC & 1.437 & 0.935 & .627 \\
\hline & $\mathrm{HSC}$ & 1.146 & 0.480 & .263 \\
\hline & Undergraduate & $.70869367 *$ & 0.189 & .003 \\
\hline
\end{tabular}

*. The mean difference is significant at the 0.05 level.

The Post-hoc comparison using the Games-Howell method indicated that the mean difference between Post Graduate level and the Undergraduate level is significant $(\mathrm{MD}=.709, \mathrm{SE}=0.189, \mathrm{p}=.003)$. Hence our hypothesis that the socio-economic factor (education level) does not affect determining factors of stock investment has been rejected for the investment training component. However, Below SSC, SSC, and HSC groups do not differ significantly from each other and we failed to reject our null hypothesis for these education levels. No significant differences have been observed for other factor components concerning different education levels under this study. 4.3.3 Investors' occupational background and factors affecting investment decision

Table 8 depicts the ANOVA results of the relationship between investors' occupational background and dominant determining factors in the investment decision. Levene's Test of Homogeneity of Variances has been significant for one factor and Welch's Robust Tests of Equality of Means has been used as a measure of the adjusted F statistic. Table 8: ANOVA for Investors' occupation and investment decision factors (Between Groups)

\begin{tabular}{|l|c|c|c|c|}
\hline \multicolumn{1}{|c|}{ Factor components } & Sum of Squares & Mean Square & F & Sig. \\
\hline Fundamental Analysis & 3.588 & 0.897 & 0.893 & .471 \\
\hline Investment Training & 4.800 & 1.200 & 1.210 & .312 \\
\hline Technical Analysis & 9.095 & 2.274 & 2.402 & .055 \\
\hline Advocacy Service & 6.695 & 1.674 & 1.722 & .151 \\
\hline Trade House Proximity & 3.836 & 0.959 & 0.957 & .435 \\
\hline
\end{tabular}

ANOVA shows no significant differences in the effect of investors' occupational background on determinants of investment decisions. Games-Howell Post-hoc test also indicates no significant differences among different occupational backgrounds (Business, Govt. service, Agriculture, Private Services, and others) of the investors. Hence, we failed to reject the null hypothesis and concludes that investors' occupational backgrounds have no significant effect on actors affecting investment decisions of sub-urban investors.

\subsubsection{Professional investment training and factors affecting investment decision}

The study investigates the impact of professional investment training on factors of stock investment of sub-urban investors. Investment training has been categorized and coded as Non-certificate training, Certificate Training, Diploma Course, Graduation, and Post-Graduation courses. Levene's Test of Homogeneity of Variances is found 
significant and a One-way ANOVA has been used to derive the finding and presented in the following table. Table 9: ANOVA for professional investment training and factor components of stock investment

\begin{tabular}{|l|c|c|c|c|}
\hline \multicolumn{1}{|c|}{ Factor components } & Sum of Squares & Mean Square & F & Sig. \\
\hline Fundamental Analysis & 1.196 & .299 & .290 & .884 \\
\hline Investment Training & 2.059 & .515 & .504 & .733 \\
\hline Technical Analysis & 2.374 & .594 & .584 & .675 \\
\hline Advocacy Service & 4.921 & 1.230 & 1.242 & .298 \\
\hline Trade House Proximity & 7.576 & 1.894 & 1.968 & .106 \\
\hline
\end{tabular}

ANOVA figures indicate no significant effect of professional investment training on determining factors of stock investment of sub-urban investors. Tukey-HSD for multiple comparisons also reveals no significant mean differences among the different levels of investment training. It can be assumed that as investment training is a highly loaded component of factors determining in stock investment, there are no significant differences in opinion about the necessity of training for investment in shares. Hence, we failed to reject our null hypothesis that investment training level has no significant effect on the determents of stock investment.

\subsubsection{Investment length (in years) and factors affecting investment decisions}

Investment tenure of the investment measured in years has been taken into consideration in evaluating the effect on factors of investment. Five Groups were created and coding accordingly assigning 5 different levels from $0-5$ years to 20 years and above. Levene's Test of Homogeneity of Variances has been found significant for two factors. Therefore, we applied Welch Robust Tests of Equality of Means statistic.

Table 10: ANOVA for investment tenure and factor components

\begin{tabular}{|c|c|c|c|c|c|}
\hline Factor components & & Sum of Squares & Mean Square & F & Sig. \\
\hline Fundamental Analysis & & 14.264 & 3.566 & 3.998 &. $\mathbf{0 0 5} *$ \\
\hline Investment Training & 3.603 & .901 & .897 & .469 \\
\hline Technical Analysis & 14.538 & 3.634 & 4.088 & .004 \\
\hline Advocacy Service & 7.734 & 1.933 & 2.013 & .099 \\
\hline Trade House Proximity & 1.783 & .446 & .436 & .783 \\
\hline
\end{tabular}

*The mean difference is significant at the 0.05 level

Table 10 shows that there is a statistically significant difference in opinion for fundamental analysis $\{F(4,95)$ $=3.998, \mathrm{p}=0.005\}$ and technical analysis $\{\mathrm{F}(4,95)=4.088, \mathrm{p}=0.004\}$ of the determinants of stock investment. The effect size under Cohen's d Criteria, calculated using eta squired was 0.14 for fundamental analysis and 0.15 for technical analysis respective indicates the large effect of these factor components based on investment length of the sub-urban investors. Hence, our hypothesis has been rejected for fundamental analysis and technical analysis components. No significant differences have been observed for other influential determinants of investment decisions.

The Games-Howell Post Hoc Tests of multiple comparisons indicate that factor score of technical analysis differs between the investors who are engaged in stock business in between 0-5 years to 6-10 years $(\mathrm{MD}=.751$, $\mathrm{SE}=0.223, \mathrm{p}=.014)$.

Table 11: Games-Howell Post Hoc Tests of multiple comparison lengths of investment

Dependent Variable: Factor score of Technical analysis

\begin{tabular}{|c|c|c|c|c|}
\hline $\begin{array}{l}\text { (I) Investors involvement } \\
\text { with stock market (years) }\end{array}$ & $\begin{array}{l}\text { (J) Investors involvement } \\
\text { with stock market (years) }\end{array}$ & $\begin{array}{c}\text { Mean Difference } \\
(\mathrm{I}-\mathrm{J})\end{array}$ & Std. Error & Sig. \\
\hline \multirow[t]{4}{*}{$0-5$ years } & $6-10$ years & $.75109140^{*}$ & .22300224 & .014 \\
\hline & 11-15 years & .07380606 & .35624568 & 1.000 \\
\hline & $16-20$ years & .21646048 & .50017621 & .991 \\
\hline & More than 20 years & 1.22419419 & .54974005 & .317 \\
\hline \multirow[t]{4}{*}{$6-10$ years } & $0-5$ years & $-.75109140^{*}$ & .22300224 & .014 \\
\hline & 11-15 years & -.67728533 & .39033066 & .438 \\
\hline & $16-20$ years & -.53463092 & .52499836 & .840 \\
\hline & More than 20 years & .47310279 & .57241695 & .912 \\
\hline \multirow[t]{4}{*}{$11-15$ years } & $0-5$ years & -.07380606 & .35624568 & 1.000 \\
\hline & 6-10 years & .67728533 & .39033066 & .438 \\
\hline & $16-20$ years & .14265441 & .59397329 & .999 \\
\hline & More than 20 years & 1.15038812 & .63627207 & .435 \\
\hline \multirow[t]{4}{*}{$16-20$ years } & $0-5$ years & -.21646048 & .50017621 & .991 \\
\hline & 6-10 years & .53463092 & .52499836 & .840 \\
\hline & 11-15 years & -.14265441 & .59397329 & .999 \\
\hline & More than 20 years & 1.00773371 & .72670999 & .650 \\
\hline
\end{tabular}




\begin{tabular}{|l|l|c|c|c|}
\hline \multicolumn{5}{|c|}{ Dependent Variable: Factor score of Technical analysis } \\
\hline \multirow{2}{*}{$\begin{array}{l}\text { (I) Investors involvement } \\
\text { with stock market (years) }\end{array}$} & $\begin{array}{l}\text { (J) Investors involvement } \\
\text { with stock market (years) }\end{array}$ & $\begin{array}{c}\text { Mean Difference } \\
(\mathrm{I}-\mathrm{J})\end{array}$ & Std. Error & Sig. \\
\hline \multirow{3}{*}{ More than 20 years } & $0-5$ years & -1.22419419 & .54974005 & .317 \\
\cline { 2 - 5 } & $6-10$ years & -.47310279 & .57241695 & .912 \\
\cline { 2 - 5 } & $11-15$ years & -1.15038812 & .63627207 & .435 \\
\cline { 2 - 5 } & $16-20$ years & -1.00773371 & .72670999 & .650 \\
\hline
\end{tabular}

*The mean difference is significant at the 0.05 level

The table also shows no significant differences in opinion of the investors who are involved in the stock market for more than 10 years. This indicates that the understanding of technical analysis of investors grows with the number of years involved with the stock market and differences in opinion decreases accordingly.

\section{Conclusion and Implications}

This study extracted the factors that the investors of sub-urban areas of Bangladesh consider while making their investment decisions in the stock market. This study finds conclusive evidence that Fundamental analysis is the most dominant factor among all the factors components derived through Principal Component Analysis. Therefore, it can be inferred that investors prefer to analyze accounting information, declaration of dividends by the company, key financial ratios, corporate profitability, capital structure and fund management, company's brand value and image and related issues while making investment decisions of a company's stock. The rank order of other investment determinants is investment training, technical analysis, advocacy service, loan margin and stock category, macroeconomic factors, insider Information, and trade house proximity. Interestingly, trade house proximity becomes a highly loaded factor as the investors have given much attention to this factor. It is also noticeable that investors are less interested in macro-economic factors like the political situation of the country and interest rate fluctuations. Some investors consider insider information as an investment decision-making tool. However, they discard market rumor as an important element in decision making. It is also evident that some socio-economic variables like gender difference and education level of the investors determine the choice of factors of investment. This study is expected to contribute to the existing literature by identifying the factors that represent the forms and attitude of the general investment behavior of the sub-urban investors of Bangladesh. However, the study is subject to some limitations which open the windows for further research. Confirmatory Factor Analysis (CFA) may be pursued by taking extracted factors as the base at home and abroad considering more samples.

\section{REFERENCES:}

Afroze, T., Rahman, S. M. Z. Bristy, J. F., \& Parvin, F. (2015). Factors Influencing Investment Decisions in Capital Market: A Study of Individual Investors in Bangladesh. European Journal of Economics, Finance and Administrative Sciences. 71(January), 80-96.

Ahmad, S., (2017). Factors Influencing Individual Investors' Behavior: An Empirical Study of Pakistan Financial Markets. Journal of Business \& Financial Affairs, 6(4), 1-8.

Akhter, R., \& Ahmed, S. (2013). Behavioral Aspects of Individual Investors for Investment in Bangladesh Stock Market. International Journal of Ethics in Social Sciences, 1(1), 15-26.

Al-Qenae, R., Li, C., and Wearing, B. (2002). The Information Content of Earnings on Stock Prices: The Kuwait Stock Exchange. Multinational Finance Journal, 6(3/4), 197-221.

Al-Tamimi, H. A. H. (2006). Factors influencing individual investor behavior: an empirical study of the UAE financial markets. The Business Review, 5(2), 225-233.

Al-Tamimi, H.A.H., \& Kalli, A.A.B. (2009). Financial Literacy and Investment Decisions of UAE Investors. Journal of Risk Finance, 10(5), 500-516.

Aren, S., \& Aydemir, S. D. (2015). The factors influencing given investment choices of individuals. Procedia Social and Behavioral Sciences, 210, $126-135$.

Bajtelsmit, V. and Bernasek, A. (2001). Risk preferences and the investment decisions of older Americans, AARP Public Policy Institute Report, Washington DC: American Association of Retired Persons, 1-53.

Balke, N., \& Wohar, M. (2006). What Drives Stock Prices? Identifying the Determinants of Stock Price Movements. Southern Economic Journal, 73(1), 55-78.

Bartlett, M.S. (1954). A Note on the Multiplying Factors for Various Chi Square Approximations. Journal of the Royal Statistical Society, 16, 296-298.

Bennet, E. \& Selvam, M. (2011). Factors Influencing Retail Investors Attitude Towards Investing In Equity Stocks: A Study In Tamil Nadu. Journal of Modern Accounting and Auditing, 7(3), 316-321.

Bhatt, P. \& Sumangula, J. K. (2012). Impact of Earning Per Share on Market Value of An Equity Share: An Empirical Study on Indian Capital Market. Journal of Finance, Accounting and Management, 3(2), 1-14.

Chong, T. P., \& Lai, M. M. (2011). An empirical evidence of factors in equity selection process in Malaysia. 
African Journal of Business Management, 5(15), 6221-6232.

Collard S., (2009), Individual Investment Behavior: A brief review of research, Personal Accounts Delivery Authority, 1-32.

Faruqui, F., \& Rahman, M. H. (2013). Factors Influencing the Crash in the Share Market in Dhaka Stock Exchange. Research Journal of Finance and Accounting, 4(7), 139-147.

Farzana, W., Rahman, M. I., \& Mazumder, M. N. H. (2012). Behavioral Financing: Demographic Factors and Services of Brokerage Houses in Bangladesh. World Journal of Social Sciences, 2(4), 15-33.

Getha, N., \& Ramesh, M. (2012). A Study on Relevance of Demographic Factors in Investment Decisions. Perspectives of Innovations, Economics \& Business, 10(1), 14-27.

Grable, J. E., Lytton, R. H. (1998). Investor risk tolerance: Testing the efficacy of demographics as differentiating and classifying factors, Financial Counselling and Planning, 9 (1), 61-74.

Haque, S., \& Faruqee, M., (2013). Impact of Fundamental factors on Stock Price: A Case Based Approach on Pharmaceutical Companies Listed with Dhaka Stock Exchange. International Journal of Business and Management Invention, 2(9), 34-41.

Hossain, M. F., \& Nasrin, S. (2012). Factors Affecting Selection of Equity Shares: The Case of Retail Investors in Bangladesh. European Journal of Business and Management, 4(20), 110-124.

Jannatunnesa. (2017). An Evaluation of the Factors Influencing Investors' Perception in Bangladesh Stock Market. International Journal of Business and Management, 12(5), 89-103.

Joshi, D. J., Khushboo, A., \& Desai, R. (2011). Factors Affecting Equity Investors' Behavior. Chief patron chief patron. International Journal of Research in Commerce and Management, 2(10), 120-126.

Kadariya, S., Subedi, P., Joshi, B., \& Nyaupane, R., (2012). Investor Awareness and Investment on Equity in Nepalese Capital Market. Banking Journal, 2(1), 1-15.

Kaiser, H.F. (1970). A second generation little jiffy. Psychometrika, 35, 401-415. http://dx.doi.org/10.1007/BF02291817

Khan, F., Afrin, F., \& Rahman M. A. (2015). Factors Influencing Investors' Decisions in Stock Market Investment in Bangladesh [A Study on Khulna City]. Journal of Finance and Accounting, 3(6), 198-204.

Khan, F., Afrin, F., \& Rahman, M. A. (2015). Factors Influencing Investors' Decisions in Stock Market Investment in Bangladesh [A Study on Khulna City]. Journal of Finance and Accounting. 3(6), 198-204. doi: $10.11648 /$ j.jfa.20150306.14

Kim, K., and Nofsinger, J., (2007). The Behavior of Japanese Individual Investors During Bull and Bear Markets. Journal of Behavioral Finance, 8(3), 138-153.

Kumar, P. M., \& Sriram, B. (2018). Factors Influencing Investment Behavior of individual Investors in Middle East Countries. Asian Journal of Research in Banking and Finance, 8(5), p.68.

Merikas, A. A., Merikas, A. G., Vozikis, G. S., \& Prasad, D. (2004). Economic Factors And Individual Investor Behavior: The Case Of The Greek Stock Exchange. Journal of Applied Business Research, 20(4), 93-98.

Metawa, N., Hassan, M. K., Metawa, S., \& Safa, M. F. (2019). Impact of behavioral factors on investors' financial decisions: case of the Egyptian stock market. International Journal of Islamic and Middle Eastern Finance and Management, 12(1), 30-55, https://doi.org/10.1108/ IMEFM-12-2017-0333

Obamuyi, T. M. (2013). Factors Influencing Investment Decisions in Capital Market: a Study of Individual Investors in Nigeria. Organizations and Markets in Emerging Economies, 4(1), 141-161.

Rahman, M. T., Hossain, S. Z., \& Habibullah, M. (2017). Stock Market Crash in Bangladesh: The Moneymaking Psychology of Domestic Investors. American Journal of Theoretical and Applied Business, 3(3), 43-53. http://doi: 10.11648/j.ajtab.20170303.12

Rashid, M., \& Nishat, M. A. (2009). Satisfaction of retail investors on the structural efficiency of the market: evidence from a developing country context. Asian Academy of Management Journal, 14(2), 41-64.

Sarbabidya, S., and Saha, T. (2018). Factors Affecting Investment Decisions: A Study on Bangladesh Stock Market. Journal of Accounting, Finance and Economics, 8(2), 1-19.

Sehgal, S., \& Tripathi, V. (2007). Value effect in Indian stock market. The ICFAI Journal of Applied Finance, 13(1), 23-36.

Sevil, G., Sen, M. \& Yalama, A. (2007). Small Investor Behavior in Istanbul Stock Exchange. Middle Eastern Finance and Economics, 1, 74-79.

Tsoukalas, D. (2003). Macroeconomic factors and stock prices in the emerging Cypriot equity market. Managerial Finance, 29(4), 87-92.

Williams, G. (2007). Some Determinants of The Socially Responsible Investment Decision: A Cross-country Study. Journal of Behavioral Finance, 8(1), 43-57. 